\title{
The African Association for Lexicography: After Ten Years
}

\author{
Mariëtta Alberts, PanSALB, Pretoria, Republic of South Africa \\ (marietta@pansalb.org.za)
}

\begin{abstract}
This year it has been ten years since the establishment of AFRILEX. After an explanation of what led to its forming, this article gives a short overview of its composition and activities.

Keywords: AFRICAN ASSOCIATION FOR LEXICOGRAPHY (AFRILEX), AFRICAN LANGUAGES ASSOCIATION OF SOUTH AFRICA (ALASA), BUREAU OF THE WOORDEBOEK VAN DIE AFRIKAANSE TAAL (WAT), DICTIONARY OF SOUTH AFRICAN ENGLISH (DSAE), LINGUISTIC ASSOCIATION OF SOUTHERN AFRICA (LSSA), NATIONAL LEXICOGRAPHY UNITS (NLUs), PAN SOUTH AFRICAN LANGUAGE BOARD (PanSALB)
\end{abstract}

Opsomming: Die African Association for Lexicography: Ná tien jaar. Vanjaar is dit tien jaar sedert die totstandkoming van AFRILEX. Na 'n verduideliking wat tot sy stigting gelei het, gee die artikel 'n kort oorsig van sy samestelling en werksaamhede.

Sleutelwoorde: AFRICAN ASSOCIATION FOR LEXICOGRAPHY (AFRILEX), AFRICAN LANGUAGES ASSOCIATION OF SOUTH AFRICA (ALASA), BURO VAN DIE WOORDEBOEK VAN DIE AFRIKAANSE TAAL (WAT), DICTIONARY OF SOUTH AFRICAN ENGLISH (DSAE), LINGUISTIC ASSOCIATION OF SOUTHERN AFRICA (LSSA), NASIONALE LEKSIKOGRAFIESE EENHEDE (NLE's), PAN SUID-AFRIKAANSE TAALRAAD (PanSAT)

\section{Background}

\subsection{Feasibility study}

In 1992, a feasibility study was done to determine the need for a Southern African Institute for Lexicography. The idea for such an Institute originated at the Board of Control of the Woordeboek van die Afrikaanse Taal (WAT). The then Editor-in-Chief of the Bureau of the WAT, Dr D.J. van Schalkwyk, requested Dr M. Alberts to do the research on behalf of the Board of Control of the WAT. Prof. W. Branford was the other member of the research team. The Gencor Development Trust provided funding for the research.

Although the idea originated at the Board of Control of the WAT, the members of the Board realised that an Institute could not be established without the collaboration and consent of all stakeholders in the Southern African lexicography fraternity. It was therefore decided to do a feasibility study in this regard (see Alberts 1993). 


\subsection{Problems related to lexicography practice}

Dictionaries play a vital role in communication and communication is vital for the well-being of all citizens of a country. Dictionary users may experience communication needs due to a lack of information in dictionaries and other lexicographical information sources (e.g. word and term banks). This could be related to insufficient dictionary products and/or lexicographical practice.

The South African dictionary practice was fragmented. Different private or governmental components were established as a result of historical, cultural or organisational reasons, had the right to exist, and continued to exist due to these reasons. An Institute as proposed could serve to unite all these components.

A big problem related to insufficient dictionary products was (and still is) financing. At that stage (1992), only the official Afrikaans and English dictionary offices (the Bureau of the WAT and the Dictionary for South African English (DSAE)) received funding from the government. This was due to the bilingual policy of the country at that stage. The African languages did not receive official funding. Some dictionaries were compiled in the African languages, but these products were either university-based or private initiatives. Proper funding was needed to produce more dictionaries for better communication.

Another problem was the lack of trained lexicographers and terminologists in the country. It was thought that a Southern African Institute for Lexicography could utilise available expertise in this regard and provide in-house training.

\subsection{Research areas}

Three research areas were determined:

- the need for a Southern African Institute for Lexicography,

- collaboration between various stakeholders, and

- the structure of such an Institute.

\section{$1.4 \quad$ Target group}

All known individuals, institutions and bodies involved in lexicography and related professions formed the target group for the research. The various stakeholders forming the target group received a covering letter, an information document explaining the purpose of the research, and a questionnaire.

\subsection{Research findings}

The main concern from respondents was a lack of coordination of lexicographi- 
cal efforts. The respondents wanted collaboration, coordination, training and sharing of expertise in the field but they did not agree on a formal structure such as an Institute.

There was a big concern regarding another formal bureaucratic controlling structure. That an Institute might hamper initiatives and private activities was an underlying fear.

Several respondents suggested that a coordinating body, clearing-house or association should be established as interim structure before deciding on an institute. An association for lexicography could unite interested parties or components, allaying underlying fears regarding individual initiatives or projects. An association could provide expertise, training, information, news, etc.

\subsection{Recommendations}

\subsubsection{Institute for Southern African Lexicography}

The feasibility study indicated that the time was not ripe for the establishment of a lexicographical institute. More in-depth discussions in this regard were needed as indicated by the research findings.

\subsubsection{Professional association}

It was felt that a professional association for Southern African lexicography should be established as soon as possible to address the needs of the respondents regarding communication and the coordination of activities.

\subsubsection{Linguistic Association of Southern Africa (LSSA)}

It was suggested that the association to be established could function for the time being under the auspices of the Linguistic Association of Southern Africa (LSSA) which formed a task group for lexicography during its annual general meeting of July 1992 in Pretoria.

\subsubsection{Aims of a professional association}

The professional association should, in order to ensure autonomy, have its own constitution and should formulate its own aims and projects. Some of the aims could include:

- the establishment of a liaison office or clearing-house to coordinate projects,

- an e-mail network,

- a quarterly newsletter, 
- an accredited magazine (e.g. Lexikos in the AFRILEX Series),

- an annual conference to share professional information, and

- a general meeting (e.g. an annual general meeting or conference) to formulate a national policy regarding lexicography.

\subsubsection{Funding}

An association would require less funding than an Institute. Membership subscriptions only would not be able to sustain such an association. The people involved in the planning of such an association will have to look into funding possibilities.

\subsubsection{Imbalances}

An important aspect to be taken into consideration was the existing imbalance between public spending on Afrikaans and English in comparison with the African languages and how this imbalance should be addressed.

\subsubsection{Publishers}

Lexicography depends to a great extent on publishing houses. Some of the publishers have an excellent record regarding the publication of dictionaries. Others try to make a profit without taking the overhead and research costs involved in the lexicographical process into consideration. Publishers should be encouraged to effectively finance the research and compilation process. Should an association be established, publishers should be encouraged to support the association financially.

\subsubsection{The way forward}

It was suggested that

- all respondents should be informed of the envisaged professional association;

- all respondents who indicated interest in an association should be contacted to take part in the process of planning such an association;

- all respondents and other interested parties should be invited to become members of the envisaged association;

- a meeting should be called as soon as possible to gather stakeholders and interested parties for the establishment of such a professional association (e.g. at an annual general meeting of LSSA); 
- feedback regarding the outcomes of the feasibility study should be given to all respondents; and

- the report on the feasibility study should be available to all stakeholders and decision-makers in the field of lexicography.

\subsection{Concluding remarks}

The results indicated a keen interest in a unifying body among lexicographers and members of related professions. It was clear that there was not as yet a need for an Institute. It was strongly felt that whatever body is established, such a body should not be bureaucratically structured and should not restrict individual freedom, inter alia with regard to management and control.

The research team therefore suggested that a professional association for lexicography should be established to meet the needs of lexicographers as well as those of other interest groups.

In 1992, the report on the feasibility study was presented to the Bureau of the Woordeboek van die Afrikaanse Taal. In 1993, the Bureau of the WAT published both an Afrikaans and an English version of the report (see Alberts 1993).

\section{Testing the viability of an Association for Lexicography}

Apart from the existing dictionary units, the interests of lexicography in South Africa had up to the beginning of 1995 been served by the Linguistic Society of Southern Africa (LSSA) and the African Language Association of Southern Africa (ALASA). Lexicographers, however, felt the need for the establishment of an association dedicated to lexicography.

In March 1995, Dr M. Alberts and Prof. D. Prinsloo finally decided to draft a questionnaire to test the viability of an Association for Lexicography. The questionnaire was sent to members of LSSA, ALASA, publishers, government departments and even political parties. More than 800 questionnaires were mailed. The reaction and enthusiasm expressed by the respondents was overwhelming.

\section{The establishment of AFRILEX in 1995}

There were respondents who seriously considered the outcomes of the 1992/93 feasibility study. With the overwhelming response from the viability study, there was no option but to establish an Association for Lexicography.

On 14 July 1995, several lexicographers, academics and stakeholders came together at the Eighth International Conference of the African Languages Association of South Africa (ALASA) to establish a professional association for lexicography. At the closure of the ALASA conference, the big moment arrived, 
and at 11:00 AFRILEX, the African Association for Lexicography, was established.

Dr R.R.K. Hartmann chaired the inaugural meeting, facilitated the whole process as well as the election of office bearers of the new association. Prof. R.H. Gouws was elected Chairperson, Mrs I. Dippenaar and Prof. S. Satyo were elected Vice-Chairpersons, Dr M. Alberts Secretary-Treasurer, Prof. D.J. Prinsloo Conference Organiser, and Mr P. Harteveld, Editor of Lexikos, was co-opted to the Board.

The Bureau of the WAT granted permission to this new Association to adopt the name AFRILEX. After the establishment of the African Association for Lexicography, Lexikos also became the official mouthpiece of AFRILEX.

In the same year, the Pan South African Language Board (PanSALB) was established in accordance with Act 59 of 1995. The amendment Act of 1999 made provision for the establishment of eleven national lexicography units (NLUs). These NLUs were established as Section 21 Companies, under the supervision of Boards of Directors. The NLUs function under the auspices of PanSALB and is financed by PanSALB. Each NLU is managed by an Editor-inChief. The Bureau of the WAT and the DSAE became the NLUs for Afrikaans and English respectively, remaining where they were seated, e.g. in Stellenbosch and Grahamstown respectively. Nine African language NLUs were established and these are hosted at tertiary institutions in the geolinguistic area where the majority first-language speakers live. Employees of the NLUs are members of AFRILEX and participate regularly in AFRILEX activities.

\section{Present situation}

AFRILEX promotes and coordinates research in and the study and teaching of lexicography in Southern Africa in its broadest sense. AFRILEX aims to train lexicographers, terminologists and other language practitioners in various aspects relating to lexicographical principles and practice. It also aims to organise regular international conferences and local seminars on topics relevant at a specific time; and to publish a journal and other appropriate literature. This creates an environment conducive to the exchange of ideas and to a mutual stimulus to researchers and practitioners in the field of lexicography. AFRILEX also facilitates tutorials and training courses (e.g. Salex'97 and AFRILEX-Salex'98).

Membership of AFRILEX is open to individuals who and institutions that have an interest in lexicography.

AFRILEX is managed by a Board elected biannually by postal ballot. It holds its annual general meetings during the annual international conferences. The first AFRILEX Board drafted a constitution that was adopted at the first such meeting. Over the years some amendments were made to the constitution so as to keep it updated and relevant. 
The AFRILEX Board aims to coordinate conference dates with that of other local associations such as ALASA and LSSA, fostering an interest in the study of language. AFRILEX seeks cooperation with international associations such as the European Association for Lexicography (EURALEX), the Asian Association for Lexicography (ASIALEX), the Australian Association for Lexicography (AUSTRALEX), the Dictionary Society of North America (DSNA), etc. AFRILEX members also attend conferences of these associations whenever possible.

AFRILEX holds its international conferences by invitation at tertiary or lexicographical institutions. The Sesiu Sesotho Dictionary Unit hosted the Tenth International Conference of AFRILEX at the University of the Free State in Bloemfontein from 13-15 July 2005. The theme of this conference was "Monolingual Dictionaries for Africa". This was also the tenth birthday celebration of the establishment of AFRILEX.

The AFRILEX Board and Executive work according to portfolios and each Board member has an allocated task to fulfil, e.g.

The President oversees the activities of the association, and liaises with other associations.

The Vice-President performs the responsibilities of the President when the President cannot do so.

The Secretary keeps minutes, writes letters, and liaises with Board and general members.

The Registrar updates the address list, manages and maintains the AFRILEX database and sends the address list to Lexikos at the Bureau of the WAT.

The Treasurer changes the signatories, processes membership fees, and prepares the auditor's report.

The Organiser organises seminars and tutorials, organises the conference, and liaises with other associations (e.g. for the coordination of dates).

The Webmaster maintains the AFRILEX web page.

The Editor of Lexikos serves on the Board as ex offico member.

Each Board member tries to promote the Association at various conferences, seminars, symposiums, etc. by taking AFRILEX flyers to such gatherings. AFRILEX members also contribute to the membership drive.

Dr Alberts made the pottery trophies mounted on wood that are usually awarded to keynote speakers and the organiser of international AFRILEX conferences. She also made a big pottery AFRILEX emblem to be used by the Association during conferences or other events.

AFRILEX recognises special contributions that were made by members in honour or on behalf of AFRILEX (e.g. being a chairperson for a number of years). Deserving members are presented with a certificate of merit in recognition of their contribution. The first recipient of the certificate was Dr J.C.M.D. $\mathrm{du}$ Plessis, Editor of Lexikos. The next two recipients were the two previous chair- 
persons of AFRILEX, Proff. R.H. Gouws and D.J. Prinsloo. Their certificates were handed to them at the Tenth International Conference in July 2005.

At this stage, AFRILEX has only one honorary member, namely Prof. A.C. Nkabinde. He was presented with a certificate for exemplary service for his valuable work as lexicographer and as past vice-chairperson of AFRILEX.

AFRILEX maintains a biannual postal voting system. This system was decided upon because not all members are in a position to attend the annual general meeting. With a postal ballot, all members of the Association are able to bring out a vote.

When AFRILEX was established, it was decided to have a regular newsletter. Unfortunately the editor of this newsletter usually has to write all the articles him-/herself. In 2004/05, there was a new effort to revive the AFRILEX Newsletter.

Over several years, some of the AFRILEX members were fortunate to receive Kernerman grants. These grants enabled the recipients to continue research in lexicographical matters or to complete masters or doctoral studies in lexicography. AFRILEX members also successfully apply for grants from EURALEX, ASIALEX, AUSTRALEX, DSNA, the Lawrence Urdang Award for Lexicography, etc.

AFRILEX is in the fortunate position that it has an accredited journal such as Lexikos as its official mouthpiece. In 1991, the Bureau of the WAT had taken the initiative to start publishing a journal of lexicography called Lexikos in a publication series called AFRILEX, acronym for "lexicography in and for Africa". After the establishment of AFRILEX, Lexikos (from volume 6, published in 1996) also became the official mouthpiece of the Association. Lexikos serves to promote lexicography in its broadest sense. Members of AFRILEX are invited to share, through Lexikos, in lexicographical discussion. AFRILEX members receive Lexikos free of charge or at drastically reduced rates. With the Bureau of the WAT, AFRILEX shares responsibility for the future existence of Lexikos.

Since the establishment of AFRILEX, Pharos Publishers, one of the leading local publishers of dictionaries, sponsors or co-sponsors the Conference dinner. This is now regarded as a Conference tradition that is much appreciated by the Association.

\section{Conclusion}

Members of AFRILEX are all in one way or another involved in dictionary compilation, in different kinds of dictionary work or projects, or in an advisory capacity, or for the mere love, or addiction to lexicography:

- Some are members of the lexicography teams for the eleven National Lexicography Units (NLUs);

- Some are compiling terminology lists or technical dictionaries for Language for Special Purposes (LSP); 
- Some are members of advisory bodies (e.g. members of the Pan South African Language Board (PanSALB), members of PanSALB Sub-Committees for various focus areas, members of the Boards of Directors of the National Lexicography Units (NLUs), members of National Language Bodies (NLBs), and members of Provincial Language Committees (PLCs)) ;

- Some are members of language offices (e.g. the National Language Service (NLS), the Terminology Coordination Section (TCS), the Language Research and Development Centres (LRDCs), Language Units (LUs), etc.);

- Some are lecturers at tertiary institutions who teach courses in metalexicography and terminology;

- Some are students of lexicography and terminology; and

- Some are language practitioners such as translators, editors, interpreters, language teachers and journalists - those who cannot do their specific jobs without the assistance of dictionaries.

None of the AFRILEX members are impartial towards lexicography and they are all interested to learn more about lexicography, dictionaries and how to compile dictionaries or use them to their best advantage.

The members of AFRILEX have a responsibility towards the various speech communities they serve. A dictionary culture needs to be created and speech communities should be aware of AFRILEX. Should the lexicographical endeavours of AFRILEX and its members be known to the general public, and all the work of the South African lexicographers could be available on the envisaged Human Language Technology virtual network, then this region would be in a position to preserve the languages and develop them into functional languages in all spheres of life. The various language communities will only then be in a position to develop their communication skills to the fullest.

If all members of AFRILEX could further the aims of AFRILEX in promoting lexicography in the Southern region of Africa, AFRILEX will have a bright future.

\section{Bibliography}

AFRILEX webpage: <http://www.up.za/academic/libarts/afrilang/homelex.html>.

Alberts, M. 1993. Feasibility Study: Institute for Southern African Lexicography/Lewensvatbaarheidstudie: Instituut vir Suider-Afrikaanse Leksikografie. Stellenbosch: Bureau of the WAT. 